\title{
METODE SIMULASI HISTORIS UNTUK PERHITUNGAN NILAI VALUE AT RISK PADA PORTOFOLIO DENGAN MODEL MARKOWITZ
}

\author{
I Wayan Eka Sultra ${ }^{1 *}$, Muhammad Rifai Katili², Muhammad Rezky Friesta Payu ${ }^{3}$ \\ 1,3 Jurusan Matematika, Universitas Negeri Gorontalo, Bone Bolango 96119, Indonesia \\ 2 Jurusan Teknik Informatika, Universitas Negeri Gorontalo, Bone Bolango 96119, Indonesia \\ *Penulis Korespondensi. Email: ekasultra28@gmail.com
}

\begin{abstract}
Abstrak
Portofolio merupakan permasalahan membentuk komposisi dari berbagai aset sehingga didapatkan hasil yang optimal. Salah satu teknik dalam manajemen resiko untuk mengukur dan menilai resiko dikenal dengan metode Value at Risk, dalam VaR terdapat tiga metode yaitu metode parametrik (varian-kovarian), simulasi monte carlo dan simulasi historis. Simulasi Historis dipilih dalam penelitian ini karena tidak memerlukan distribusi normal dari returns dan menjadi salah satu model perhitungan nilai Value at Risk yang ditentukan oleh nilai masa lalu atas return aset yang dihasilkan. Tujuan dari penelitian ini adalah menentukan saham positif dengan model Markowitz kemudian menentukan nilai Value at Risk pada portofolio dengan metode simulasi historis. hasil penelitian dengan model Markowitz mendapatkan 8 saham yang memiliki expected return yang positif yaitu : BBCA, BBRI, BRPT, EXCL, ICBP, INDF, MNCN, TPIA. Dari 8 saham tersebut mendapatkan nilai eksposure terbesar adalah BBCA sebesar Rp 2.287.200.440.000 dan ekposure terkecil adalah TPIA Rp 58.899.375.000. Nilai VaR terbesar adalah EXCL sebesar Rp 236.189.538.497, nilai VaR yang tidak memiliki kerugian adalah TPIA dan ICBP karena nilai VaR dari TPIA adalah Rp 0 dan nilai VaR dari ICBP adalah Rp -1.407.719.893, nilai VaR terkecil adalah INDF sebesar Rp 18.513.213.620. Rata-rata nilai ekposure sebesar Rp 719.246.318.375 dan ratarata nilai VaR sebesar Rp 76.827.608.341,3. Dengan demikian selama nilai VaR tidak lebih tinggi dari nilai eksposure maka investor saham aman dan tidak akan mendapat kerugian.
\end{abstract}

Kata Kunci: Value at Risk; Simulasi Historis; Markowitz; Eksposure

\begin{abstract}
A portfolio concerns the formation of the composition of multiple assets to obtain optimum results. At the same time, Value at Risk is a technique in risk management to measure and assess parametrically (variant and co-variant), Monte-Carlo, and historical simulation. This research employed historic simulation because normal distribution is not required from returns and is a Value at Risk calculation model that is determined by the past value on produced return asset, in which this research aimed to determine the Markowitz model positive shares and Value at Risk in the portfolio by using historical simulation. The Markowitz model found eight shares with positive expected returns, which are as follows: BBCA, BBRI, BRPT, EXCL, ICBP, INDF, MNCN, and TPIA. The BBCA has the most significant exposure of all the shares with the amount of $R p$ 2.287.200.440.000, while the TPIA has the smallest exposure of all the shares with the amount of $R p$ 58.899.375.000. Further, the EXCL has the largest VaR with the amount of Rp 236.189.538.497, while the TPIA and ICBP had no VaR losses because the VaR of TPIA and ICBP is Rp 0 and Rp 1.407.719.893, respectively, along with the INDF as the share with the smallest VaR of Rp 18.513.213.620. The most significant exposure average is $R p$ 719.246.318.375, while the largest VaR average is $R p$ 76.827.608.341,3. As long as the VaR did not exceed the exposure value, the investors will be safe and have no loss.
\end{abstract}

Keywords: Value at Risk; Historical Simulation; Markowitz; Exposure 


\section{Pendahuluan}

Portofolio merupakan permasalahan membentuk komposisi dari berbagai aset sehingga didapatkan hasil yang optimal [1]. Analisis portofolio yang efisien perlu dilakukan untuk memecahkan masalah tersebut. Adapun tujuan pembentukan portofolio yaitu berusaha untuk memberikan keuntungan yang maksimum sesuai dengan yang diharapkan atau adanya return yang diharapkan (expected return), menciptakan resiko yang minimum dan menciptakan continuity dalam bisnis [2].

Salah satu teknik dalam manajemen resiko untuk mengukur dan menilai resiko dikenal dengan metode Value at Risk (VaR) yaitu resiko yang berkaitan dengan ketidakpastian laba pada lembaga keuangan atas portofolio perdagangannya yang disebabkan oleh adanya perubahan pada kondisi pasar investasi yang selalu berubah ubah, dalam VaR terdapat tiga metode yaitu metode parametrik (variankovarian), Simulasi Monte Carlo dan Simulasi Historis [3]. Simulasi Historis dipilih dalam penelitian ini karena tidak memerlukan distribusi normal dari Returns dan metode simulasi historis menjadi salah satu model perhitungan nilai Value at Risk yang ditentukan oleh nilai masa lalu atas return aset yang dihasilkan [4]. VaR juga merupakan pengukuran resiko secara kuantitatif yang mengestimasi potensi kerugian maksimal (maximum potential loss) yang mungkin terjadi pada masa depan yang akan dihadapi pada jangka waktu tertentu dan pada tingkat kepercayaan tertentu. Secara sederhana VaR menjawab pertanyaan seberapa besar (dalam persen atau sejumlah uang) suatu organisasi, perusahaan dan individu dapat diuntungkan selama waktu investasi dengan tingkat kepercayaan tertentu [5].

Dalam meminimumkan resiko pada saat investor akan berinvestasi atau nilai resiko dari masing-masing saham dapat diperkecil dengan model Markowitz. Konsep dasar dari model Markowitz adalah memberi suatu bahan masukan kepada para investor untuk menghindari risiko dan memberikan keuntungan yang maksimal pada setiap keputusan insvestai. Investasi yang baik adalah investasi yang jauh dari resiko kerugian [6]. Pada dasarnya investor menghindari dengan adanya risiko. Investor yang rasional akan memilih untuk memegang portofolio yang efisien dengan memaksimalkan keuntungan yang diharapkan untuk tingkat risiko tertentu atau meminimalkan risiko untuk tingkat return tertentu [7].

Pada saat ini, bisnis saham merupakan investasi yang paling banyak diminati. Sebagaimana bentuk inventasi lain, investasi saham memiliki kelebihan dan kekurangan tersendiri. Salah satu kelebihan investasi saham adalah memberikan potensi return yang tinggi dan berkesinambungan. Kebanyakan orang berinvestasi dengan cara menaruh sebagian dana di pasar modal. Para investor dalam melakukan investasi saham pasti menginginkan keuntungan yang berupa dividen maupun capital gain, akan tetapi dalam berinvestasi saham juga memiliki resiko. Seringkali masalah yang ditemukan oleh para investor dalam berinvestasi, khususnya dengan instrumen saham, adalah bagaimana mengoptimalkan portofolio yang dimilikinya [8][9].

Berbagai penelitian mengenai pembentukan portofolio optimal dengan model Markowitz dapat dilihat pada [10][11]. Adapun penelitian yang membahas investasi saham pasar modal syariah dengan model markowitz dan model indeks tunggal dapat ditemukan pada [12]. Selain itu terdapat penelitian yang menganalisis investasi saham pada perusahaan go public yang dapat dilihat pada [13]. Pada penelitian yang akan dilakukan terdapat sedikit perbedaan dengan penelitian sebelumnya dimana akan ditambahkan metode simulasi historis untuk perhitungan nilai VaR karena pada penelitian sebelumnya hanya menghitung nilai dari model Markowitz dan analisis investasi saham.

Berdasarkan uraian di atas, maka dilakukan penelitian tentang perhitungan nilai Value at Risk pada portofolio dengan model Markowitz. Pada penelitian ini model Markowitz berperan untuk medapatkan saham positif sebagai sampel untuk perhitungan nilai Value at Risk. Selain itu, penelitian ini juga dituliskan program berupa algoritma perhitungan portofolio menggunakan aplikasi $\mathrm{R}$, sehingga dapat mempermudah investor dalam memperoleh presentase dana yang akan diinvestasikan dengan memasukan data yang dibutuhkan, studi kasus pada penelitian dilakukan pada saham-saham dari berbagai perusahaan yang terdaftar ke dalam saham LQ45 index (JKLQ45). 


\section{Metode Penelitian}

Data yang digunakan pada penelitian ini adalah data sekunder untuk nilai harga penutupan Close Price saham mingguan yang diambil pada interval Februari 2019 - Januari 2020. Data tersebut didapat dari Yahoo Finance melalui official website https://finance.yahoo.com. Adapun langkahlangkah analisis data yang dilakukan dalam penelitian ini adalah:

1. Menentukan portofolio saham positif menggunakan model Markowitz.

2. Menghitung expected return $(\mathrm{E}(R i))$, varians dan standar deviasi return saham.

3. Menghitung matriks kovarian dan korelasi antar return saham.

4. Menentukan jumlah aset susunan portofolio berdasarkan nilai expected return.

5. Menghitung bobot menggunakan metode MVEP.

6. Menghitung nilai VaR menggunakan metode simulasi historis

\section{Hasil dan Pembahasan}

\subsection{Deskripsi Return Saham LQ45}

Analisis deskriptif merupakan tahap awal eksplorasi data yang dilakukan untuk mendapatkan gambaran umum dari data penelitian. Statistika deskriptif dari data penelitian ini ditampilkan pada Tabel 1.

Tabel 1. Statistika Deskriptif Return Saham dari Februari 2019 - Januari 2020

\begin{tabular}{cccccccccccc}
\hline $\begin{array}{c}\text { Daftar } \\
\text { Saham }\end{array}$ & Mean & Varians & Min & Max & Range & $\begin{array}{c}\text { Daftar } \\
\text { Saham }\end{array}$ & Mean & Varians & Min & Max & Range \\
\hline ADRO & $-0,0022$ & 0,0045 & $-0,12$ & 0,17 & 0,29 & INTP & $-0,0036$ & 0,0023 & $-0,13$ & 0,10 & 0,23 \\
AKRA & $-0,0095$ & 0,0025 & $-0,15$ & 0,10 & 0,25 & ITNG & $-0,0152$ & 0,0046 & $-0,15$ & 0,13 & 0,28 \\
ANTM & $-0,0055$ & 0,0039 & $-0,11$ & 0,17 & 0,28 & JSMR & $-0,0012$ & 0,0020 & $-0,11$ & 0,12 & 0,23 \\
ASII & $-0,0055$ & 0,0011 & $-0,09$ & 0,07 & 0,16 & KLBF & $-0,0023$ & 0,0014 & $-0,14$ & 0,08 & 0,22 \\
BBCA & 0,0027 & 0,0005 & $-0,08$ & 0,08 & 0,16 & LPPF & $-0,0163$ & 0,0085 & $-0,43$ & 0,17 & 0,60 \\
BBNI & $-0,0048$ & 0,0012 & $-0,08$ & 0,07 & 0,15 & MEDC & $-0,0068$ & 0,0029 & $-0,13$ & 0,17 & 0,29 \\
BBRI & 0,0025 & 0,0010 & $-0,08$ & 0,06 & 0,15 & MNCN & 0,0122 & 0,0058 & $-0,27$ & 0,19 & 0,46 \\
BBTN & $-0,0077$ & 0,0024 & $-0,13$ & 0,09 & 0,22 & PGAS & $-0,0074$ & 0,0032 & $-0,23$ & 0,11 & 0,34 \\
BMRI & $-0,0001$ & 0,0010 & $-0,09$ & 0,08 & 0,17 & PTBA & $-0,0129$ & 0,0032 & $-0,21$ & 0,16 & 0,37 \\
BRPT & 0,0180 & 0,0044 & $-0,11$ & 0,22 & 0,33 & PTPP & $-0,0097$ & 0,0036 & $-0,15$ & 0,15 & 0,30 \\
BSDE & $-0,0042$ & 0,0020 & $-0,11$ & 0,10 & 0,21 & PWON & $-0,0047$ & 0,0016 & $-0,09$ & 0,09 & 0,18 \\
CPIN & $-0,0029$ & 0,0049 & $-0,20$ & 0,17 & 0,37 & SCMA & $-0,0050$ & 0,0029 & $-0,10$ & 0,11 & 0,20 \\
ERAA & $-0,0070$ & 0,0114 & $-0,34$ & 0,35 & 0,69 & SMGR & $-0,0012$ & 0,0018 & $-0,11$ & 0,08 & 0,20 \\
EXCL & 0,0062 & 0,0024 & $-0,14$ & 0,12 & 0,26 & SRIL & $-0,0084$ & 0,0011 & $-0,13$ & 0,05 & 0,18 \\
GGRM & $-0,0076$ & 0,0027 & $-0,23$ & 0,11 & 0,35 & TKIM & $-0,0075$ & 0,0120 & $-0,31$ & 0,38 & 0,69 \\
HMSP & $-0,0116$ & 0,0019 & $-0,18$ & 0,07 & 0,25 & TLKM & $-0,0004$ & 0,0008 & $-0,08$ & 0,07 & 0,14 \\
ICBP & 0,0011 & 0,0007 & $-0,10$ & 0,05 & 0,16 & TPIA & 0,0081 & 0,0029 & $-0,13$ & 0,16 & 0,29 \\
INCO & $-0,0034$ & 0,0033 & $-0,14$ & 0,12 & 0,26 & UNTR & $-0,0059$ & 0,0019 & $-0,12$ & 0,11 & 0,23 \\
INDF & 0,0001 & 0,0014 & $-0,13$ & 0,07 & 0,19 & UNVR & $-0,0044$ & 0,0006 & $-0,08$ & 0,06 & 0,15 \\
INDY & $-0,0152$ & 0,0064 & $-0,20$ & 0,23 & 0,43 & WIKA & $-0,0001$ & 0,0034 & $-0,13$ & 0,14 & 0,27 \\
INKP & $-0,0121$ & 0,0081 & $-0,17$ & 0,31 & 0,48 & WXKT & $-0,0091$ & 0,0030 & $-0,13$ & 0,15 & 0,28 \\
\hline
\end{tabular}

Tabel 1 menunjukkan return tiap saham bervariasi yaitu terdapat return yang tinggi dan ada return yang rendah. Dari data harga penutupan saham mingguan, rata-rata return saham tertinggi dimiliki oleh saham BRPT (Barito Pacific Tbk) dengan rata-rata return saham sebesar 0,0180 atau $1,80 \%$, sedangkan rata-rata return saham terendah dimiliki oleh saham LPPF (Matahari Departement Store Tbk) dengan rata- rata return saham sebesar $-0,0163$ atau $-1,63 \%$. Mean adalah rata-rata return yang akan diterima investor, jadi yang memiliki rata-rata keuntungan tertinggi adalah BRPT dan ratarata keuntungan terendah adalah LPPF. Mean tertinggi akan masuk pada return saham positif karena memiliki rata-rata keuntungan yang tinggi. Varians Tertinggi dimiliki oleh saham TKIM (Pabrik 
Kertas Tjiwi Kimia Tbk.) yakni sebesar 0,0120 atau 1,20\% sedangkan varians terendah dimiliki oleh saham BBCA (Bank Central Asia Tbk) yakni sebesar 0,0005 atau 0,05\%. Varians ini memberikan gambaran resiko yang dapat diterima investor ketika berinvestasi pada saham tersebut, dengan demikian saham yang memiliki resiko tinggi adalah saham TKIM sedangkan yang memiliki risiko rendah adalah saham BBCA. Nilai maksimum return tertinggi (maksimum) dimiliki oleh saham TKIM sedangkan nilai maksimum return terendah dimiliki oleh saham SRIL (Sri Rejeki Isman Tbk.) dan ICBP (Indofood CBP Sukses Makmur Tbk.).

\subsection{Penentuan Portofolio dengan Model Markowitz}

\subsubsection{Menghitung Expected Return (E(Ri)), Varians, dan Standar Deviasi Return Saham}

Nilai expected return dapat menjadi dasar pemilihan saham yang layak masuk ke portofolio. Selain expected return, nilai standar deviasi juga harus ditentukan. Standar deviasi dapat memberikan gambaran tentang resiko yang harus ditanggung oleh investor ketika berinvestasi pada saham tersebut. Hasil perhitungan expected return dan standar deviasi dari return saham dengan bantuan microsoft excel ditampilkan pada Tabel 2.

Tabel 2. Hasil perhitungan expected return, varians dan standar deviasi pada return saham

\begin{tabular}{cccccccccc}
\hline \multirow{2}{*}{ No } & $\begin{array}{c}\text { Daftar } \\
\text { Saham }\end{array}$ & $E\left(R_{i}\right)$ & Varians & Standar Deviasi & No & $\begin{array}{c}\text { Daftar } \\
\text { Saham }\end{array}$ & $E\left(R_{i}\right)$ & Varians & Standar Deviasi \\
\hline 1 & ADRO & $-0,0022$ & 0,0045 & 0,0671 & 22 & INTP & $-0,0035$ & 0,0023 & 0,0476 \\
2 & AKRA & $-0,0095$ & 0,0025 & 0,0495 & 23 & ITNG & $-0,0152$ & 0,0046 & 0,0680 \\
3 & ANTM & $-0,0055$ & 0,0039 & 0,0620 & 24 & JSMR & $-0,0012$ & 0,0020 & 0,0451 \\
4 & ASII & $-0,0054$ & 0,0011 & 0,0324 & 25 & KLBF & $-0,0023$ & 0,0014 & 0,0369 \\
5 & BBCA & $\mathbf{0 , 0 0 2 6}$ & $\mathbf{0 , 0 0 0 5}$ & $\mathbf{0 , 0 2 2 9}$ & 26 & LPPF & $-0,0162$ & 0,0085 & 0,0921 \\
6 & BBNI & $-0,0048$ & 0,0012 & 0,0344 & 27 & MEDC & $-0,0068$ & 0,0029 & 0,0535 \\
7 & BBRI & $\mathbf{0 , 0 0 2 4}$ & $\mathbf{0 , 0 0 1 0}$ & $\mathbf{0 , 0 3 1 6}$ & $\mathbf{2 8}$ & MNCN & $\mathbf{0 , 0 1 2 1}$ & $\mathbf{0 , 0 0 5 8}$ & $\mathbf{0 , 0 7 6 0}$ \\
8 & BBTN & $-0,0076$ & 0,0024 & 0,0492 & 29 & PGAS & $-0,0074$ & 0,0032 & 0,0565 \\
9 & BMRI & $-0,0001$ & 0,0010 & 0,0308 & 30 & PTBA & $-0,0128$ & 0,0032 & 0,0564 \\
10 & BRPT & $\mathbf{0 , 0 1 7 9}$ & $\mathbf{0 , 0 0 4 4}$ & $\mathbf{0 , 0 6 6 3}$ & 31 & PTPP & $-0,0096$ & 0,0036 & 0,0603 \\
11 & BSDE & $-0,0041$ & 0,0020 & 0,0447 & 32 & PWON & $-0,0047$ & 0,0016 & 0,0397 \\
12 & CPIN & $-0,0028$ & 0,0049 & 0,0697 & 33 & SCMA & $-0,0049$ & 0,0029 & 0,0535 \\
13 & ERAA & $-0,0070$ & 0,0114 & 0,1068 & 34 & SMGR & $-0,0012$ & 0,0018 & 0,0424 \\
14 & EXCL & $\mathbf{0 , 0 0 6 2}$ & $\mathbf{0 , 0 0 2 4}$ & $\mathbf{0 , 0 4 9 0}$ & 35 & SRIL & $-0,0083$ & 0,0011 & 0,0330 \\
15 & GGRM & $-0,0076$ & 0,0027 & 0,0515 & 36 & TKIM & $-0,0074$ & 0,0120 & 0,1094 \\
16 & HMSP & $-0,0115$ & 0,0019 & 0,0432 & 37 & TLKM & $-0,0003$ & 0,0008 & 0,0287 \\
17 & ICBP & $\mathbf{0 , 0 0 1 0}$ & $\mathbf{0 , 0 0 0 7}$ & $\mathbf{0 , 0 2 7 2}$ & $\mathbf{3 8}$ & TPIA & $\mathbf{0 , 0 0 8 1}$ & $\mathbf{0 , 0 0 2 9}$ & $\mathbf{0 , 0 5 3 7}$ \\
18 & INCO & $-0,0034$ & 0,0033 & 0,0572 & 39 & UNTR & $-0,0059$ & 0,0019 & 0,0439 \\
19 & INDF & $\mathbf{0 , 0 0 0 1}$ & $\mathbf{0 , 0 0 1 4}$ & $\mathbf{0 , 0 3 7 3}$ & 40 & UNVR & $-0,0044$ & 0,0006 & 0,0253 \\
20 & INDY & $-0,0152$ & 0,0064 & 0,0802 & 41 & WIKA & $-0,0805$ & 0,0034 & 0,0581 \\
21 & INKP & $-0,0121$ & 0,0081 & 0,09 & 42 & WXKT & $-0,0091$ & 0,0030 & 0,0550 \\
\hline
\end{tabular}

Tabel 2 menunjukkan nilai expected return dari standar deviasi (resiko) jika berinvestasi pada saham-saham tersebut. Dari tabel 2 diketahui bahwa terdapat 8 saham yang memiliki expected return yang positif yaitu : BBCA, BBRI, BRPT, EXCL, ICBP, INDF, MNCN, TPIA. Nilai expected return positif berarti saham ini mampu memberikan return yang optimal bagi investor, sehingga sahamsaham ini layak untuk diperhitungkan masuk dalam portofolio optimal dan terdapat 34 saham yang tidak layak masuk dalam portofolio optimal karena memiliki expected return negatif berarti sahamsaham tersebut tidak mampu memberikan return optimal bagi investor sehingga tidak layak masuk dalam portofolio optimal.

Untuk saham yang memiliki expected return positif, expected return saham tertinggi ada pada saham BRPT dengan return sebesar 0,0179 atau 1,79\% dan expected return terendah yaitu INDF dengan return sebesar 0.0001 atau $0,01 \%$. Risiko saham tertinggi ada pada saham MNCN dengan 
risiko sebesar 0,0760 atau $7,60 \%$ dan risiko saham terendah ada pada ICBP dengan risiko sebesar 0.0272 atau 2,72\%. Risiko saham tertinggi pada MNCN sebanding dengan expected return yang diterima investor. Hal ini menunjukkan bahwa semakin besar expected return yang akan diterima investor, semakin tinggi juga risiko yang harus diterima saat berinvestasi pada saham tersebut.

\subsubsection{Menghitung Bobot dengan Metode MVEP (Mean Variance Efficient Portofolio)}

Untuk menghitung bobot dengan metode MVEP diperlukan matriks kovarian, selain matriks kovarian matriks korelasi juga perlu dianalisa. Saham yang digunakan dalam pembentukan portofolio adalah saham-saham yang memiliki expected return yang positif. Perhitungan matriks kovarian dan matriks korelasi dilakukan dengan bantuan software R, dengan hasil sebagai berikut.

Tabel 3. Hasil perhitungan kovarian antar return saham

\begin{tabular}{ccccccccc}
\hline & BBCA & BBRI & BRPT & EXCL & ICBP & INDF & MNCN & TPIA \\
\hline BBCA & 0,000525 & 0,000427 & 0,000119 & 0,000665 & 0,000223 & 0,000358 & 0,000312 & 0,000501 \\
BBRI & 0,000427 & 0,000999 & 0,000540 & 0,000551 & 0,000057 & 0,000282 & 0,000243 & 0,000260 \\
BRPT & 0,000119 & 0,000540 & 0,004399 & 0,000414 & 0,000110 & 0,000123 & 0,000450 & 0,000478 \\
EXCL & 0,000665 & 0,000551 & 0,000414 & 0,002408 & 0,000357 & 0,000526 & 0,000173 & 0,000867 \\
ICBP & 0,000223 & 0,000057 & 0,000109 & 0,000357 & 0,000743 & 0,000780 & 0,000037 & 0,000454 \\
INDF & 0,000358 & 0,000282 & 0,000123 & 0,000526 & 0,000780 & 0,001393 & 0,000033 & 0,000523 \\
MNCN & 0,000312 & 0,000243 & 0,000450 & 0,000173 & 0,000037 & 0,000033 & 0,005786 & 0,000663 \\
TPIA & 0,000500 & 0,000260 & 0,000478 & 0,000867 & 0,000454 & 0,000523 & 0,000663 & 0,002885 \\
\hline
\end{tabular}

Tabel 3 menunjukkan nilai kovarian antar return saham. Berdasarkan tabel 3 diketahui bahwa nilai kovarian antar return saham semuanya bernilai positif. Hal ini berarti bahwa penggabungan antar dua saham dalam portofolio cenderung bergerak ke arah yang sama sehingga jika 8 saham ini dikombinasikan akan menghasilkan return yang baik.

Tabel 4. Hasil perhitungan korelasi antar return saham

\begin{tabular}{ccccccccc}
\hline & BBCA & BBRI & BRPT & EXCL & ICBP & INDF & MNCN & TPIA \\
\hline BBCA & 1,000000 & 0,589311 & 0,078586 & 0,591032 & 0,357338 & 0.418140 & 0,179245 & 0,406840 \\
BBRI & 0,589311 & 1,000000 & 0,257682 & 0,355229 & 0,065791 & 0,238858 & 0,101031 & 0,153034 \\
BRPT & 0,078586 & 0,257682 & 1,000000 & 0,127210 & 0,060506 & 0,049598 & 0,089165 & 0,134196 \\
EXCL & 0,591032 & 0,355229 & 0,127210 & 1,000000 & 0,266632 & 0,287002 & 0,046415 & 0,328807 \\
ICBP & 0,357338 & 0,065791 & 0,060506 & 0,266632 & 1,000000 & 0,766004 & 0,018010 & 0,310236 \\
INDF & 0,418140 & 0,238858 & 0,049598 & 0,287002 & 0,766004 & 1,000000 & 0,011528 & 0,260879 \\
MNCN & 0,179245 & 0,101031 & 0,089165 & 0,046415 & 0,018010 & 0,011528 & 1,000000 & 0,162234 \\
TPIA & 0,406840 & 0,153034 & 0,134196 & 0,328807 & 0,310236 & 0,260879 & 0,162234 & 1,000000 \\
\hline
\end{tabular}

Setelah diperoleh kovarian antar return saham, langkah selanjutnya adalah menghitung bobot portofolio dengan metode Mean Variance Efficient Portofolio (MVEP). Perhitungan bobot portofolio dengan metode MVEP membutuhkan invers matriks variance-covariance dari data return saham pembentuk portofolio. Nilai kovarian pada Tabel 3 dapat ditulis dalam notasi matriks sebagai berikut.

$$
\sum=\left[\begin{array}{llllllll}
0,000525 & 0,000437 & 0,000119 & 0,000665 & 0,000223 & 0,000358 & 0,000312 & 0,000501 \\
0,000427 & 0,000999 & 0,000540 & 0,000551 & 0,000057 & 0,000282 & 0,000243 & 0,000260 \\
0,000119 & 0,000540 & 0,004399 & 0,000414 & 0,000110 & 0,000123 & 0,000450 & 0,000478 \\
0,000665 & 0,000551 & 0,000414 & 0,002408 & 0,000357 & 0,000526 & 0,000173 & 0,000867 \\
0,000223 & 0,000057 & 0,000109 & 0,000357 & 0,000743 & 0,000780 & 0,000037 & 0,000454 \\
0,000358 & 0,000282 & 0,000123 & 0,000526 & 0,000780 & 0,001393 & 0,000033 & 0,000523 \\
0,000312 & 0,000243 & 0,000450 & 0,000173 & 0,000037 & 0,000033 & 0,005786 & 0,000663 \\
0,000500 & 0,000260 & 0,000478 & 0,000867 & 0,000454 & 0,000523 & 0,000663 & 0,002885
\end{array}\right]
$$


Selanjutnya invers matriks variance-covariance dihitung dengan bantuan software R. Invers matriks variance-covariance yang diperoleh dapat ditulis sebagai berikut.

$$
\Sigma^{-1}=\left[\begin{array}{cccccccc}
5125,2602 & -1605,7815 & 228,4839 & -763,0560 & -516,8234 & -245,5421 & -255,3043 & -486,4931 \\
-1605,7815 & 1825,3946 & -203,2840 & -5,9185 & 685,3932 & -365,0026 & 37,0733 & 116,5740 \\
228,4839 & -203,2840 & 259,2476 & -36,1072 & -80,5183 & 39,4541 & -28,8353 & -54,5657 \\
-763,0560 & -5,9185 & -36,1072 & 656,4558 & -508509 & -2,4288 & 19,7703 & -45,2185 \\
-516,8234 & 685,3932 & -80,5183 & -50,8509 & 3629,9549 & -1947,7833 & -24,7061 & -167,6993 \\
-245,5421 & -365,0026 & 39,4541 & -2,4288 & -1947,7833 & 1929,1516 & 31,1376 & 33,9351 \\
-255,3043 & 37,0733 & -28,8353 & 19,7703 & -24,7061 & 31,1376 & 196,2164 & 83,1447 \\
-486,4931 & 116,5740 & -54,5657 & -45,2185 & -167,6993 & 33,9351 & 83,1447 & 482,5266
\end{array}\right]
$$

Setelah invers matriks variance-covariance diperoleh, selanjutnya akan dihitung bobot masingmasing saham pada portofolio dengan menyubtitusikan matriks variance-covariance ke dalam rumus

$$
\mathbf{w}=\frac{\sum^{-1} 1_{n}}{1_{n}^{T} \Sigma^{-1} 1_{n}}
$$

dimana

$$
1_{n}=\left[\begin{array}{l}
1 \\
1 \\
1 \\
1 \\
1 \\
1 \\
1 \\
1
\end{array}\right]
$$

Berdasarkan subtitusi matriks diatas dan dengan bantuan software R diperoleh bobot saham pembentuk portofolio. Bobot portofolio disajikan dalam Tabel 5.

Tabel 5. Bobot Portofolio

\begin{tabular}{cc}
\hline Saham & Bobot Saham $\left(w_{i}\right)$ \\
\hline BBCA & 0,5137 \\
BBRI & 0,1681 \\
BRPT & 0,0430 \\
EXCL & 0,0789 \\
ICBP & 0,5298 \\
INDF & 0,1829 \\
MNCN & 0,0203 \\
TPIA & 0,0131 \\
\hline
\end{tabular}

Tabel 5 menunjukkan bahwa saham yang memiliki bobot terbesar adalah saham ICBP (Indofood CBP Sukses Makmur Tbk.), sedangkan saham yang memiliki bobot terkecil adalah saham TPIA (Chandra Asri Petrecemical Tbk.). Dengan demikian bobot yang tertinggi nantinya dapat memberikan Nilai VaR yang tidak merugikan pada perhitungan VaR time hirizon 7 hari maksimal.

\subsection{Menghitung Nilai VaR dengan Menggunakan Metode Simulasi Historis}

Populasi dalam penelitian ini adalah seluruh perusahaan yang terdaftar di Indeks LQ45 selama periode 2019-2020. Pemilihan sampel dalam penelitian dilakukan dengan mengoptimalkan saham menggunakan model markowitz dan mendapatkan hasil expected return yang positif. 
Tabel 6. Saham dengan expected return positif yang terdaftar di Index LQ45 selama periode 2019- 2020

\begin{tabular}{ccl}
\hline No & Kode & \multicolumn{1}{c}{ Nama Emiten } \\
\hline 1 & BBCA & Bank Central Asia Tbk. \\
2 & BBRI & Bank Rakyat Indonesia Tbk. \\
3 & BRPT & Barito Pasifik Tbk. \\
4 & EXCL & XL Axiata Tbk. \\
5 & ICBP & Indofod CBP Sukses Tbk. \\
6 & INDF & Indofod Sukses Makmur Tbk. \\
7 & MNCN & Medis Nusantara Tbk. \\
8 & TPIA & Chandra Asri Petrecemical Tbk. \\
\hline
\end{tabular}

Selanjutnya menghitung nilai return dan di urutkan mulai dari yang terendah sampai ke return tertinggi. Dalam penelitian ini data return yang dipergunakan adalah selama 1 tahun dengan tingkat kepercayaan sebesar $95 \%$.

Tabel 7. Jumlah data saham penelitian

\begin{tabular}{cccc}
\hline No & Emiten & Jumlah Data & 5\% Jumlah Data \\
\hline 1 & BBCA & 52 & 2,6 \\
2 & BBRI & 52 & 2,6 \\
3 & BRPT & 52 & 2,6 \\
4 & EXCL & 52 & 2,6 \\
5 & ICBP & 52 & 2,6 \\
6 & INDF & 52 & 2,6 \\
7 & MNCN & 52 & 2,6 \\
8 & TPIA & 52 & 2,6 \\
\hline
\end{tabular}

Pada Tabel 7 jumlah data penelitian sama semua sehingga percentile 5\% dari jumlah data akan sama semua yaitu 2,6 dan dibulatkan menjadi 3. VaR time horizon 7 hari saham maksimal merupakan kerugian yang terjadi dalam 7 hari kedepan berdasarkan pembelian jumlah saham maksimal yang ditawarkan, berikut hasil perhitungan VaR time horizon 7 hari saham maksimal.

Tabel 8. VaR time horizon 7 hari saham maksimal

\begin{tabular}{cccccccc}
\hline \multirow{2}{*}{ No } & \multirow{2}{*}{ Emiten } & \multicolumn{2}{c}{ Price Close } & \multirow{2}{*}{ Volume (Rp) } & Eksposure (Rp) & Percentile 5\% & \multirow{2}{*}{ VaR (Rp) } \\
\cline { 3 - 7 } & & $\mathrm{p} 3$ & $\mathrm{p} 4$ & & & & \\
\hline 1 & BBCA & 26.800 & 27.450 & 85.343 .300 & 2.287 .200 .440 .000 & 0.023964280 & 145.016 .570 .801 \\
2 & BBRI & 3.770 & 3.900 & 466.010 .700 & 1.757 .203 .409 .000 & 0,033901551 & 157.612 .488 .056 \\
3 & BRPT & 560 & 600 & 349.540 .000 & 195.742 .400 .000 & 0,068992871 & 35.730 .422 .081 \\
4 & EXCL & 2.340 & 2.640 & 316.262 .500 & 740.054 .250 .000 & 0,120627987 & 236.189 .538 .497 \\
5 & ICBP & 10.425 & 10.400 & 21.257 .200 & 221.606 .310 .000 & $-0,002400961$ & -1.407 .719 .893 \\
6 & INDF & 7.425 & 7.625 & 35.455 .800 & 263.259 .315 .000 & 0,026579637 & 18.513 .213 .620 \\
7 & MNCN & 910 & 945 & 252.752 .800 & 230.005 .048 .000 & 0,037740327 & 22.966 .353 .568 \\
8 & TPIA & 5.550 & 5.550 & 10.612 .500 & 58.899 .375 .000 & 0 & 0 \\
\hline
\end{tabular}

Tabel 8 menunjukan bahwa nilai eksposure terbesar adalah BBCA sebesar Rp 2.287.200.440.000 dan ekposure terkecil adalah TPIA Rp 58.899.375.000. Nilai VaR terbesar adalah EXCL sebesar Rp 236.189.538.497 menandakan bahwa kerugian maksimal 7 hari kedepan pada perusahaan EXCL sebesar Rp 236.189.538.497, nilai VaR yang tidak memiliki kerugian adalah TPIA dan ICBP karena nilai VaR dari TPIA adalah 0 dan nilai VaR dari ICBP adalah Rp -1.407.719.893, nilai VaR terkecil adalah INDF sebesar Rp 18.513.213.620 menandakan bahwa kerugian maksimal 7 
hari kedepan pada perusahaan ICBP sebesar Rp 18.513.213.620. Rata-rata nilai VaR time horizon 7 hari kedepan pada indeks LQ45 yaitu sebesar Rp 76.827.608.341,3.

Investasi adalah penanaman modal yang diharapkan dapat menghasilkan tambahan dana pada masa yang akan datang [8]. Seseorang berinvestasi dengan tujuan untuk menghasilkan keuntungan yang akan meningkatkan kesejahteraan [14]. VaR dapat didefinisikan sebagai estimasi kerugian maksimum yang akan didapat selama periode waktu (time period) tertentu dalam kondisi pasar normal pada tingkat kepercayaan (confidence interval) tertentu [15].

Berdasarkan perhitungan dalam penelitian ini didapat rata-rata nilai ekposure indeks LQ45 sebesar Rp 719.246.318.375 dan rata-rata nilai VaR time horizon 7 hari kedepan sebesar $\mathrm{Rp}$ 76.827.608.341,30. Semakin tinggi nilai eksposure maka kemungkinan nilai VaR pun akan semakin tinggi.

\section{Kesimpulan}

Penentuan portofolio dengan model markowitz menghasilkan 8 saham yang memiliki expected return yang positif yaitu: BBCA, BBRI, BRPT, EXCL, ICBP, INDF, MNCN dan TPIA. Dari 8 saham tersebut mendapatkan hasil, nilai eksposure terbesar adalah BBCA sebesar Rp 2.287.200.440.000 dan ekposure terkecil adalah TPIA Rp 58.899.375.000. Nilai VaR terbesar adalah EXCL sebesar Rp 236.189.538.497, nilai VaR yang tidak memiliki kerugian adalah TPIA dan ICBP karena nilai VaR dari TPIA adalah 0 dan nilai VaR dari ICBP adala Rp -1.407.719.893, nilai VaR terkecil adalah INDF sebesar Rp 18.513.213.620. Rata-rata nilai ekposure sebesar Rp 719.246.318.375 dan rata-rata nilai VaR sebesar Rp 76.827.608.341,30. Dengan demikian selama nilai VaR tidak lebih tinggi dari nilai Eksposure maka investor saham aman dan tidak akan mendapat kerugian.

\section{Referensi}

[1] M. Markowitz, "Portfolio Selection. The Journal of Finance," vol. 7, pp. 77-91, 1952.

[2] N. P. E. C. S. and G. M. Sudiartha, "Pembentukan Portofolio Optimal Menggunakan Model Markowitz,” vol. 8, no. 7, pp. 4213-4238, 2019, doi: 10.24843/2019.v08.i07.p08.

[3] M. N. N. R. and M. Khoiruddin, "Konsistensi Pengukuran Value at Risk pada Saham Syariah dengan Metode Historis," Manag. Anal. J., vol. 7, no. 1, pp. 1-11, 2018, doi: 10.15294/maj.v7i1.13759.

[4] R. Astuti, "Perbandingan Perhitungan Value At Risk Pada Indeks JII dan Indeks LQ45 dengan Metode Simulasi Historis Rini Astuti, Suripto, K. Bagus," pp. 1-12.

[5] S. A. Heryanti, "Perhitungan Value at Risk Pada Portfolio Optimal: Studi Perbandingan Saham Syariah dan Saham Konvensional," Ikonomika, vol. 2, no. 1, pp. 75-84, 2017, doi: 10.24042/febi.v2i1.943.

[6] F. Irham, Pengantar Teori Portofolio dan Analisis Investasi. bandung: alfabeta, 2015.

[7] S. Pracanda and N. Abundanti, "Pembentukan Portofolio Optimal Dengan Menggunakan Model Markowitz Pada Saham Indeks Idx30 Di Bursa Efek Indonesia,” E-Jurnal Manaj. Univ. Udayana, vol. 6, no. 2, pp. 802-829, 2017.

[8] H. Hartono, Teori Portofolio dan Analisis Investasi. yogyakarta: BPFE, 2017.

[9] S. Husnan, Dasar-dasar Teori Portofolio dan Analisis Sekuritas. Edisi Kelima. yogyakarta: UUP AMP YKN, 2006.

[10] S. Uswatun, "Pembentukan Portofolio Optimal dengan Model Markowitz dan Indeks Tunggal pada Saham-saham Jakarta Islamic Index (JII).," pp. 21-31, 2017.

[11] N. Nuryanto dan S. Tresno, "Historical Simulation untuk Menghitung Value At Risk pada Portofolio Optimal Berdasarkan Single Index Model Menggunakan GUI Matlab,” pp. 58-70, 
2018.

[12] T. Triwahyuni, "Analisis Investasi Portofolio Saham Pasar Modal Syariah dengan Model Markowitz dan Model Indeks Tunggal,” pp. 72-83, 2019.

[13] E. Asliana, "Analisis Investasi Saham Go Public Sektor Pertanian di Bursa Efek Indonesia," no. 55, pp. 391-410, 2006.

[14] N. Nurkhalisa and S. Jikrillah, "Analisis Value at Risk pada Saham Yang Terdapat Dalam Jakarta Islamic Index (JII) Periode Juni 2017-Mei 2018," Sains Manaj. dan Kewirausahaan, vol. 3, no. 2, pp. 124-133, 2019.

[15] S. Suhadi, "Evaluasi perhitungan Value at Risk dengan simulasi Monte Carlo dan Simulasi historis pada tiga bank badan usaha milik negara (BUMN)," 2012. 